\title{
АНТРОПОЛОГИЯ МИГРАЦИЙ
}

DOI: $10.33876 / 2311-0546 / 2022-3 / 222-242$

(C) О.В. Кульбачевская

\section{СОЦИАЛЬНО-ЭКОНОМИЧЕСКОЕ САМОЧУВСТВИЕ МОСКВИЧЕЙ И МИГРАЦИОННАЯ СИТУАЦИЯ В СТОЛИЧНОМ РЕГИОНЕ*}

В статье представлены результаты исследования социально-экономической ситуачии, характера миграционных отношений и возможного влияния миграции на сочиально-экономическое самочувствие жителей г. Москвы. Были выявлены основные сочиальные и экономические проблемы местных жителей, их отнотение к иностранным трудовым мигрантам, дана оценка конфликтного потенциала в сфере труда. Согласно результатам исследования, треть жителей столиць находится в затруднительной сочиально-экономической ситуации. В последние годы наблюдается тендениия увеличения уровня тревожности населения по поводу потери работы и источников доходов. Несмотря на то, что на московском рынке труда отсутствует жесткая конкуренция между местным населением и мигрантами, в ряде трудовых сфер возможно напряжение. Труд иностранных мигрантов, в основном малоквалифичированный, в столице необходим, но он не оказывает серьезного влияния на экономику города и страны. Москвичи в недостаточной степени настроены на интеграиию всех работаюших в столиче мигрантов. В первую очередь они готовы интегрировать тех, кто хорошо знает русский язык и хочет остаться в России. Миграчионные отночения в столице можно охарактеризовать как в большей степени нейтральные, но конфликтный потенциал (активное неприятие мигрантов со стороны части местного населения) существует и составляет 15\%. В подавляющем большинстве москвичи не связывают свои проблемы соииально-экономического характера с присутствием в регионе мигрантов.

Ключевые слова: сочиально-экономическая ситуачия; рынок труда, иностранные трудовые мигранты, миграчионные отношения, интеграчионные установки, конфликтный потенциал, Москва

Ссылка при цитировании: Кульбачевская О.B. Социально-экономическое самочувствие москвичей и миграционная ситуация в столичном регионе // Вестник антропологии, 2022. № 1. С. 222-242.

\footnotetext{
Кульбачевская Ольга Вячеславовна - научный сотрудник центра этнополитических исследований, Институт этнологии и антропологии им. Н.Н. Миклухо-Маклая РАН (Российская Федерация, 119334, Москва, Ленинский пр., 32А). Эл. почта: ola_kul@mail.ru

* Выполнено в рамках проекта РФФИ № 21-011-31820 ОПН (рук. А.М. Белов)
} 
(C) O.V. Kulbachevskaya

\section{SOCIO-ECONOMIC WELL-BEING OF MOSCOVITES AND THE MIGRATION SITUATION IN THE CAPITAL REGION}

The article presents the results of a study of the socio-economic situation, migration relations, and the possible impact of migration on the socio-economic well-being of residents of Moscow. The study identifies the main social and economic problems of residents and their attitude to foreign labor migrants and assesses the conflict potential in the area of labor. According to the study results, one-third of the capital residents are in a difficult socio-economic situation. In recent years, there has been an increase in the level of anxiety of the population about the possible loss of work and sources of income. Although there is no fierce competition between the local population and migrants in the Moscow labor market, tension is possible in a number of labor spheres. The labor of foreign migrants, mostly low-skilled, is necessary for the capital, but it does not seriously impact the economy of the city and the country. Moscovites are insufficiently disposed to integrate all migrants working in the capital. First, they are ready to integrate those who have a good command of Russian and are ready to stay in Russia. Migration relations in the capital can be characterized as mostly neutral, but the conflict potential (active rejection of migrants by the local population) exists and amounts to $15 \%$. The vast majority of Moscovites do not associate their socioeconomic problems with migrants in the region.

Keywords: socio-economic situation; labor market, foreign labor migrants, migration relations, integration attitudes, conflict potential, Moscow

For Citation: Kulbachevskaya, O.V. 2022. Socio-Economic Well-Being of Moscovites and the Migration Situation in the Capital Region. Herald of Anthropology (Vestnik Antropologii) 1: 222-242.

Author Info: Kulbachevskaya, Olga V. - Researcher, Institute of Ethnology and Anthropology RAS (Moscow, Russia). E-mail: ola_kul@mail.ru

Funding: The research was carried out within the framework of the Russian Foundation for Basic Research. Project No. 21-011-31820 OPN "Migration processes and their impact on the socio-economic development of Central Russia: comparative analysis of the province and megalopolis (the case of the Kostroma region and Moscow)".

На протяжении длительного времени Москва является наиболее миграционно привлекательным регионом страны. Экономический рост российской столицы формирует спрос на трудовую миграцию. На долю столицы приходится треть иностранных трудовых мигрантов, приехавших работать в Россию. В основном это граждане Киргизии, Узбекистана и Таджикистана. Очевидно, что миграция в Россию и Москву из этих бывших союзных республик обусловлена экономическими факторами. Однако немаловажным является также изучение вопроса влияния миграции на социально-экономическое развитие принимающих регионов. 
Исследования западных ученых показывают, что влияние внутрирегиональной миграции зависит от этапов и характера экономического развития той или иной страны. Внутрирегиональная миграция может оказывать положительное влияние на экономический рост в периоды индустриализации и роста городов (Yap 1976; Greenwood 1971), давать положительный эффект в случае притока квалифицированной рабочей силы (Liu, Shen 2014), однако в определенные исторические периоды эффект внутрирегиональной миграции оказывается почти нулевым (Etzo 2008). По мнению ряда зарубежных исследователей, оценить влияние внешней трудовой миграции на экономику принимающей страны сложнее. Тем не менее, в этом направлении проводились исследования, например, влияния внешней трудовой миграции на отдельные ниши рынка труда (Hugo 2009).

Работы российских исследователей по данной теме до недавнего времени были посвящены влиянию межрегиональной миграции на экономическое развитие России и ее регионов. Результаты исследований показали, что внутренняя миграция почти не влияет на уровень заработных плат и уровень безработицы (Вакуленко 2013; Коровкин, Долгова, Единак 2013). В 2020 г. появилась работа российских специалистов, в которой впервые проведен анализ взаимовлияния миграции и экономического развития регионов России с использованием данных по долговременной, внутренней и внешней трудовой миграции (Кариева, Мкртчян, Флоринская 2020). На основании результатов эмпирического исследования авторы пришли к выводу, что ни один из видов миграции «не оказывает значимого статистического влияния ни на один из показателей социально-экономического развития регионов России» (Там же).

Следует отметить многолетние исследования Института этнологиии антропологии РАН совместно с Сетью этнологического мониторинга, в ходе которых изучалась взаимосвязь социальной ситуации, миграционных отношений и ситуации на рынке труда в регионах России. По результатам исследований были изданы научные труды (Тишков, Степанов и др. 2019; Мартынова 2018; Степанов 2016; Степанов 2015; Кульбачевская 2015; Миграция и мигранты в России и мире 2015-2016 и др.).

В июле-августе 2021 г. автором статьи был проведен массовый опрос населения г. Москвы по теме миграции ${ }^{1}$. В ходе исследования было опрошено 200 жителей столицы. В задачи исследования входило изучение социально-экономической ситуации, характера миграционных отношений, а также выявление возможного влияния миграции на социально-экономическое самочувствие жителей столицы. В статье представлены результаты опроса. По ряду вопросов проводился сравнительный анализ с привлечением данных массовых опросов москвичей в предыдущие годы.

\section{Социально-демографический портрет и идентичность москвичей}

В ходе исследования летом 2021 г. было опрошено 100 женщин и 100 мужчин. Половину респондентов составили мужчины и женщины среднего возраста (от 30 до 59 лет), в равных долях (по 25\%) в выборке представлены молодые женщины и мужчины (18-29 лет), а также пожилые люди (старше 60 лет). Две трети опрошенныхлюди с высшим образованием, менее десятой части - с неоконченным высшим.

\footnotetext{
${ }^{1}$ Опрос проводился путем анкетирования по методике Сети этнологического мониторинга и раннего предупреждения конфликтов. Анкета была дополнена и применена новая методика подсчета данных.
} 
Пятая часть респондентов имеет среднее специальное образование, десятая часть среднее. Лишь два процента составляют люди с начальным, неполным средним образованием и люди без образования.

Около двух третей (60\%) опрошенных москвичей в настоящее время работают; пятая часть - пенсионеры; учащихся, в том числе, совмещающих учебу с работой, менее десятой части. Безработные составляют 4,5\% от общего числа опрошенных москвичей. Среди работающих бо́льшая часть (74\%) - это люди, не зарабатывающие тяжелым физическим трудом. Тяжелыми работами и работами средней тяжести занимается около пятой части опрошенных. Занимаются домашним хозяйством 4\% респондентов.

Подавляющее большинство опрошенных (91\%) являются старожилами, из них почти две трети родились в столице и около трети проживают в городе более 10 лет. Тех, кто приехал в Москву совсем недавно - менее двух лет назад - совсем немного (2,5\% от общего числа опрошенных). Среди тех, кто проживает в столице не с рождения, подавляющее большинство переселилось в столицу из других российских регионов. География выхода таких респондентов охватывает практически всю страну, это субъекты РФ Центральной России, Поволжья, Юга России, Северного Кавказа, Урала, Сибири, Дальнего Востока). Небольшая часть (7\% от общего числа опрошенных) приехали в Москву из других государств, а именно из республик бывшего СССР. Из них 70\% - выходцы с Украины, на втором месте стоит Белоруссия, затем Молдавия.

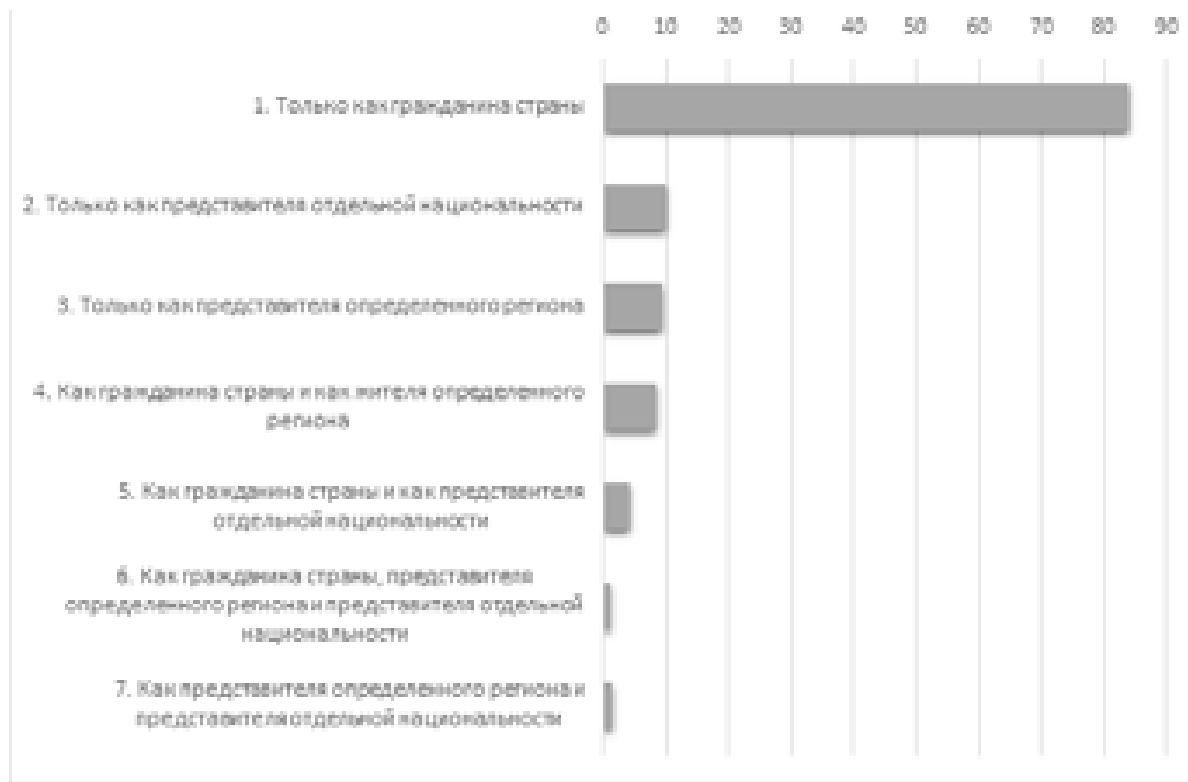

Рис. 1. Как Вас должны воспринимать окружающие?

Fig. 1. How should others perceive you?

Почти $80 \%$ москвичей, принявших участие в исследовании - русские, вторыми по численности стоят люди, определившие свою национальность как россияне (7\%), среди других - немногочисленных - групп заметны украинцы (3\%). Чуть более десятой части респондентов имеют двойную этническую идентичность. В подавляющем большинстве случаев у этих москвичей первой национальностью 
является «русский/русская». В нескольких случаях респонденты определяли себя как «русский», а вторую национальность указывали «россиянин». Около десятой части $(8 \%)$ не дали ответ на вопрос о национальной принадлежности. Единичны случаи региональной самоидентификации при ответе на данный вопрос («сибиряк», «я с Урала»), а также самоопределения по религиозному признаку («православная»). Один процент опрошенных называет своей национальностью «советский человек».

У москвичей выявлена высокая степень гражданской идентичности $75 \%$ опрошенных предпочитают, чтобы окружающие в повседневной жизни воспринимали их как граждан России, причем подавляющее большинство из них указали только этот вариант ответа. Для пятой доли характерна двойная идентичность: больше половины из них определяют себя одновременно как гражданина страны и жителя определенного региона, для остальных важна и гражданская и этническая идентичность. Десятая часть опрошенных идентифицирует себя исключительно по этническому признаку, почти столько же - как москвичи.

\section{Экономика Москвы и социально-экономическое самочувствие ее жителей}

В условиях пандемии можно было ожидать серьезного осложнения социальноэкономической ситуации не только в регионах России, но и в ее столице. Однако уже осенью текущего года стало ясно, что по большинству показателей экономического развития Москва перекрыла допандемические показатели. Надолю городаприходится пятая часть суммарного валового регионального продукта (ВРП) страны. Этот основной показатель, характеризующий развитие и размеры экономики, в столице за последние 10 лет вырос на 12\% (что почти в 2,5 раза превышает среднероссийский уровень). Москва также является лидером по инвестиционной привлекательности в России. Объем инвестиций в основной капитал вырос по сравнению с 2010 г. на $2,7 \%$ и составляет $18,6 \%$ общероссийского объема инвестиций (RT на русском 2021). За прошедший год увеличились не только инвестиции, но и объемы промышленности и строительства. По итогам первого полугодия 2021 года, согласно данным Росстата, Москва занимает третью позицию по росту промышленности в стране. В столице увеличились объемы промышленного производства, в первую очередь в обрабатывающей сфере (+27,4\% к показателям предыдущего года) и в сфере водоснабжения (+41,6\%) (РИА рейтинг: Россия сегодня 2021). В столице наблюдается положительная динамика оборота розничной торговли.

Рост среднемесячной начисленной заработной платы работников организаций столицы по сравнению с прошлым годом составил почти 10\%. Реальные доходы, рассчитанные с учетом индекса потребительских цен, превысили 5\%. Несмотря на то, что за прошедший год в Москве произошел небольшой рост безработицы $(+0,7$ процентных пункта), она находится в десятке российских регионов с самым низким уровнем безработицы (6-е место) (Социально-экономическое положение регионов РФ 2021). На конец сентября 2021 г. уровень зарегистрированной безработицы составил $0,5 \%$ от численности рабочей силы. По словам заммэра Москвы по вопросам экономической политики и имущественно-земельных отношений Владимира Ефимова, значительного роста безработицы в Москве в пандемию удалось избежать «За счет взвешенного подхода к введению ограничительных мер и программы поддержки городского бизнеса общим объемом около 90 миллиардов рублей» (ТАСС 
2021a). Кроме того, в столице активно поддерживают людей, которые остались без работы путем выплат пособий и содействия в трудоустройстве. В городе действует крупнейший государственный кадровый оператор по поиску работы - столичная служба занятости, где представлено 300 тыс. вакансий (Официальный сайт Мэра Москвы 2021).

В ноябре 2021 г. мэр Москвы Сергей Собянин в программе «Наш город. Диалог с мэром» на канале «ТВ Центр» заявил, что столица, выйдя в текущем году на траекторию устойчивого роста, будет развиваться дальше. Поэтому, полагает мэр столицы, москвичи должны чувствовать уверенность в завтрашнем дне (ТВЦ 2021).

Мы привели официальную статистику и заявления официальных лиц. А каким образом сами жители столицы дают оценку социально-экономической ситуации в столичном регионе? В ходе многолетних исследований Института этнологии и антропологии РАН совместно с Сетью этнологического мониторинга мы задавали жителям города вопрос о том, как они оценивают свое материальное положение за последний год. На диаграмме 2 представлена динамика этой оценки москвичей, из которой видно, что, несмотря на то, что за последние годы в целом наблюдается снижение числа тех жителей столицы, кто в материальном отношении чувствует себя хорошо, тем не менее, растет число тех, кто оценивает свое материальное положение как в целом нормальное. Также можно заметить, что в предпандемийный 2019 г. общая ситуация с материальным положением была более негативна, чем в текущем году. К середине 2021 г. мы наблюдаем, пусть и небольшое, но сокращение численности москвичей, находящихся в затруднительной и тяжелой материальной ситуации. И все же, как нам представляется, ситуацию, когда почти треть населения города испытывает серьезные материальные затруднения, вряд ли можно назвать благополучной.

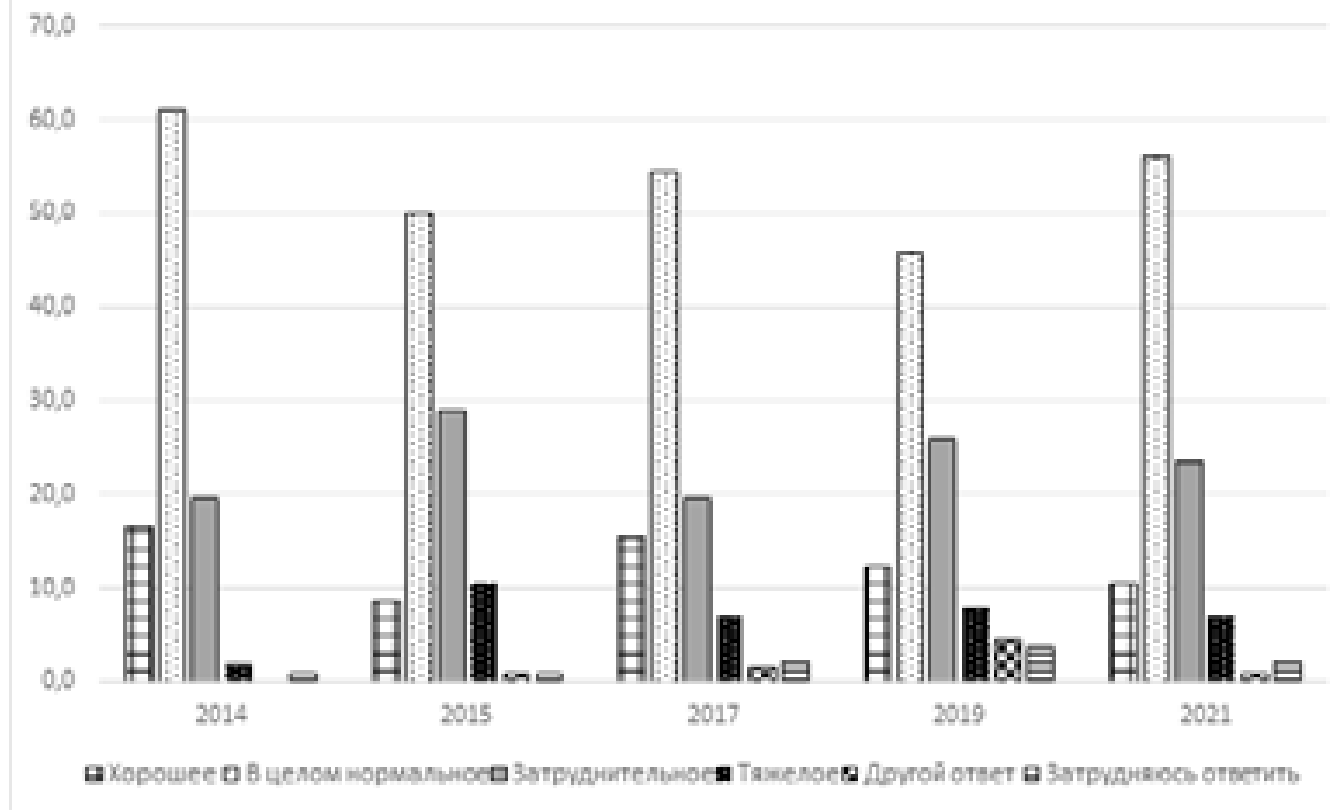

Рис. 2. Оченка жителей Москвы своего материального положения за последний год, в \%.

Fig. 2. Assessment of their financial situation over the past year by Moscow residents, $\%$. 
Что касается уверенности в завтрашнем дне, то у 44\% работающих москвичей иногда возникают опасения потерять работу. Если к ним добавить пятую часть от общего числа работающих, которые задумываются об этом часто, то получается, что две трети населения столицы не может быть твердо уверена в своем благополучном социально-экономическом положении в будущем. Более того, в последние годы наблюдается тенденция увеличения числа москвичей, кто в той или иной степени опасается лишиться работы.

В ходе опроса летом 2021 г. мы просили москвичей назвать основные проблемы социально-экономического характера, которые, по их мнению, существуют в Москве. Более десятой части опрошенных не видят каких-либо проблем в столичном регионе. К москвичам, придерживающимся такого мнения, относятся в первую очередь люди с нормальным материальным положением (60\%), а также, что удивительно, люди с затруднительным материальным положением (25\%). А вот люди с хорошим достатком реже говорят об отсутствии социально-экономических проблем в столице, таких респондентов чуть больше десятой части.

Москвичей, полагающих, что проблем социально-экономического характера в Москве, наоборот, очень много, ровно столько же, сколько и тех, кто проблем не видит. Такого мнения, опять же, придерживаются в большинстве своем люди с нормальным материальным достатком, но в этом случае с ними единодушны и люди, находящиеся в затруднительной и тяжелой материальной ситуации.

Распределение ответов респондентов по конкретным социально-экономическим проблемам, которые при опросе были предложены как варианты ответов, показало, что для большинства москвичей все эти проблемы существуют и имеют равнозначную актуальность (табл. 1). К ним относятся:

- Низкий уровень жизни. Это постоянно растущие цены на все. Особенно москвичей в этом плане беспокоят высокие цены на продовольственные товары, качество которых к тому же не соответствует стоимости, а также рост цен на услуги ЖКХ, качество которых опять же не удовлетворяет москвичей, в том числе капремонт. Многие отмечают дороговизну жизни в столице на фоне низких зарплат и пенсий. Отмечаются также маленькие социальные выплаты и пособия, недостаточная поддержка со стороны государства матерей одиночек, низкий уровень поддержки безработных, высокая налоговая нагрузка на физических лиц. Некоторые комментарии респондентов красноречиво говорят о бедственном социально-экономическом положении части москвичей: «Несоответствие цены и качества на продукты питания и минимальной заработной платы. Хватает только на еду и коммунальные услуги и сидеть дома» (м, 32 года), «Маленькая зарплата, нищенское существование» (м, 49 лет).

- Более, чем десятая часть москвичей (14\%) считает для себя невозможным карьерный рост, в том числе вследствие коррупции.

- И для такого же числа респондентов (14\%) актуальна проблема отсутствия хороших высокооплачиваемых вакансий на местном рынке труда. Некоторые увязывают это экономической отсталостью, закрытием крупных предприятий, разрушением промышленного производства. Все это влечет за собой безработицу, в том числе рост безработных среди людей предпенсионного возраста. 
Таблица 1

\section{Какие основные проблемы социально-экономического характера существуют в Вашем регионе?}

\begin{tabular}{l|c}
\hline Варианты ответов & \% от опрошенных \\
\hline 1) низкий уровень жизни (доход, уровень цен на продукты & 14,5 \\
питания, невозможность откладывать и копить деньги) & 14,4 \\
\hline 2) невозможен карьерный рост & 14,3 \\
\hline 3) отсутствие хороших вакансий на местном рынке труда & 14,3 \\
\hline 4) Проблем очень много & 14,2 \\
\hline 5) Нет проблем & 14,2 \\
\hline 6) Ваш вариант & 14,1 \\
\hline 7) Затрудняюсь ответить & \\
\hline
\end{tabular}

Москвичи, принявшие участие в опросе, обозначили еще ряд проблем, актуальных, по их мнению, для столичного региона:

- Неэффективная система образования на всех уровнях, дороговизна образовательных услуг, отсутствие возможности развития молодежи за счет высоких цен на образование, кружки, секции.

- $\quad$ Высокие цены на медицинские услуги, которые к тому же имеют ненадлежащее качество.

- Труднодоступность жилья в столище. Это высокие цены, влекущие за собой большие сложности с приобретением жилья и улучшением жилищных условий.

- Перенаселенность и, как следствие, перегруженность общественного транспорта, загруженность дорог, очень плотная и широкая застройка, проблемы с парковками. Некоторых москвичей раздражают постоянные стройки в больших объемах.

- Ухудшение экологической обстановки, повышенный уровень шума, грязный воздух.

- Повымение пенсионного возраста.

- Сложности с наймом москвичей на низкоквалифицированные рабочие позиции

- Плохая работа правоохранительных органов и проблемы с безопасностью в городе, в т.ч. вследствие неэффективной борьбы с организованной преступностью и незаконным оборотом наркотиков; полицейский произвол.

- Проблемы в молодежной среде. Плохое образование ведет к падению уровня культуры у молодежи; недостаточная вовлеченность молодых москвичей в социум, отсутствие воспитания у них любви к труду.

- Нецелесообразное освоение бюджетных средств, а именно бесконечное перекладывание асфальта и бордюров, буквально каждый год, хотя они прекрасно простоят и 5, и 10 лет. Отсюда постоянная грязь и ремонтные работы, которым нет конца.

- Ослабление устойчивых сочиальных связей, утрата локальной культуры.

- Большое социальное расслоение, больщая разница в доходах. В этой связи 
звучали предложения такого рода: «Законодательно привязать зарплату сотрудников к доходу компаний, чтобы сократить огромный разрыв в доходах рабочих и владельцев».

- Отсутствие четкой идеологии развития страны и региона.

- Около десятой части опрошенных выступали против ущемления гражданских прав, нарушения местными властями федеральных законов, коррупции, фактического отсутствия выборности власти.

- Очень небольшое число опрошенных москвичей воспринимают мигрантов в своем городе как проблему. Тем не менее, такие люди есть (2,5\%). Они против постоянного наплыва мигрантов, против, по их мнению, повышенной мигрантской преступности, их раздражает плохое знание мигрантами русского языка.

В целом можно сказать, что по оценке большинства москвичей, в таком большом и развитом, по сравнению с другими регионами России, мегаполисе существует целый ряд проблем социально-экономического характера. Вследствие этого треть москвичей имеет неудовлетворительный уровень заработка и доходов, у двух третей столичных жителей нет твердой уверенности в завтрашнем дне, а 4\% респондентов в своих комментариях в ходе опроса употребляли такие слова, как «бедность», «нищета», «нищенское существование», «отсутствие перспектив».

Лишь небольшая, десятая, часть опрошенных москвичей считает, что в их городе нет никаких проблем и все отлично развивается в естественном темпе и порядке. Однако подавляющее большинство (80\%) видит необходимость проведения определенных мероприятий в городе для улучшения качества жизни. В ходе опроса респонденты могли выбрать из готового списка мероприятий и задач, а также указать свой вариант ответа. Распределение ответов по конкретным мероприятиям показало, что, по мнению москвичей, необходимо осуществлять все предложенные в анкете меры практически в равной степени (табл. 2).

Таблица 2

Мероприятия, необходмые для улучшения качества жизни в Москве

\begin{tabular}{|c|c|}
\hline Варианты ответа & \% от опрошенных \\
\hline 1) повышение пенсий & 10,2 \\
\hline 2) введение дополнительных льгот для семей с детьми & 10,2 \\
\hline 3) контроль цен на продукты первой необходимости & 10,1 \\
\hline 4) снижение цен на ЖКХ & 10,1 \\
\hline 5) поддержка малого и среднего бизнеса & 10,0 \\
\hline $\begin{array}{l}\text { 6) восстановление заводов } \\
\text { (например, экскаваторный), развитие ткацких фабрик }\end{array}$ & 10,0 \\
\hline 7) развитие сельского хозяйства & 9,9 \\
\hline 8) мероприятия не нужны, все отлично развивается исторически & 9,9 \\
\hline 9) Ваш вариант & 9,9 \\
\hline 10) затрудняюсь ответить & 9,8 \\
\hline
\end{tabular}

В первую очередь респонденты указывали на необходимость повышения пенсий и зарплат. По мнению опрошенных, семьи с детьми и малоимущие семьи нуждаются 
в получении дополнительных льгот. Нужно усилить поддержку людей пенсионного и предпенсионного возраста. Москвичи устали от постоянного роста цен на продукты первой необходимости и полагают, что назрела необходимость контроля не только цен на товары, но и контроля их качества.

Многих не устраивают высокие цены на услуги ЖКХ. Остро воспринимается вопрос капремонта домов. Например, по плану дома, построенные 40 лет назад, подлежат капремонту не ранее, чем в 2039 г. При этом дома уже нуждаются в ремонте. Жители вынуждены делать его за счет своих средств, при этом оплачивая по квитанциям капитальные работы в отдаленном будущем. Ряд опрошенных ратует за контроль бюджетных потоков в сфере ЖКХ.

Отдельной темой стоят здравоохранение и образование. Нужно повысить качество профессиональной подготовки врачей и учителей, подняв им зарплаты, и сделать более доступными медицинские и образовательные услуги (последние в том числе за счет увеличения числа бюджетных мест). При этом жители города устали от навязывания такого рода услуг. По мнению москвичей, в столице все еще сохраняется необходимость в строительстве дополнительных медицинских центров.

В экономическом плане необходимо усиливать поддержку малого и среднего бизнеса, не допуская массового закрытия такого рода предприятий и не создавая условий, когда заниматься бизнесом становится невозможно; нужно восстанавливать заводы и развивать сельское хозяйство. Требуется обеспечить население рабочими местами, в том числе за счет малого бизнеса. Сделать более доступным жилье.

У жителей есть претензии и к тому, каким образом развивается инфраструктура города. Они выступают против неконтролируемой, незаконной застройки. Нужно лучше обустраивать территории на окраинах города, больше озеленять город, создавать скверы, парки, пространства для прогулок, зоны для езды на электротранспорте. Город все больше бетонируется, застраивается торговыми центрами, платными парковками вместо необходимых центров развития для молодежи, парковых зон и др. Вызывают раздражение бесконечные работы по замене бордюров и детских площадок, которые зачастую выглядят бессмысленными и фактически принципиально не улучшают инфраструктуру. Те же ресурсы лучше было бы потратить на более продуманное благоустройство районов города с привлечением талантливых городских архитекторов и ландшафтных дизайнеров.

По мнению некоторых респондентов, в столице не хватает социальных мероприятий для молодежи.

Довольно часто респонденты демонстрировали недоверие к региональной власти. По мнению таких опрошенных, слова со стороны официальных лиц расходятся с делом. Звучали обвинения в коррупции и нецелесообразном и нецелевом использовании бюджетных средств, в том числе и со стороны органов местного самоуправления. По мнению некоторых москвичей, местные власти мало думают о населении, мало делают для него, но получают большие зарплаты. В пример приводились все те же замены бордюрной плитки и асфальта по 2 раза в год ввиду некачественно выполняемых работ. Также высказывались мнения о том, что местные власти в корне не улучшают социально-экономическую ситуацию, а сосредоточены на бесконечных коммерческих застройках, в то время как строительство детских площадок является пунктом отчетности. 
Некоторые москвичи полагают, что Москва нуждается в демократичных свободных выборах мэра, в обновлении кадрового состава всей исполнительной власти, усилении общественного контроля за законодательной властью, перераспределении бюджета с увеличением расходов на социальную сферу и сокращением представительских расходов и зарплат высших и главных должностей госслужбы.

Отметим, что один из опрошенных заявил о том, что необходимо улучшать ситуацию и развивать не только Москву, но и другие регионы России.

Та небольшая часть респондентов $(2,5 \%)$, которая воспринимает мигрантов как проблему, влияющую на социально-экономическую жизнь местного населения, предлагает ограничить приток мигрантов в Москве или ратует за выдворение всех мигрантов из города.

По результатам опроса, подавляющее большинство москвичей (80\%) полагает, что в столичном регионе необходимо возрождать практически все отрасли хозяйства, в первую очередь тяжелую (особенно машиностроение) и легкую промышленность. Москва должна иметь собственные производства. Нужно восстановить фабрики и заводы, которые были разрушены. Очень многие москвичи говорили о необходимости развития в Московском регионе сельского хозяйства, животноводства, овощеводства, лесного хозяйства. Жителям столицы очень не хватает качественной сельскохозяйственной продукции, необходимо возродить сельскохозяйственные рынки, чтобы местные производители имели возможность реализовывать свою продукцию. Обращалось внимание на химическую, авиационную промышленность. Город, по мнению некоторых опрошенных, нуждается в развитии малого и среднего предпринимательства.

Что касается непроизводственной сферы, то для Москвы актуально улучшение работы таких отраслей как здравоохранение, культура, образование, жилищное хозяйство, туризм, собственные ІТ-технологии.

Рассмотрим теперь, каким образом складываются отношения между москвичами, полагающими, что в их городе существует целый ряд социальных и экономических проблем, и иностранными трудовыми мигрантами, и каким видят местные жители влияние миграции на социально-экономическую среду города.

\section{Местное население и мигранты на рынке труда}

В начале нужно сказать, что в первую волну пандемии коронавируса в 2020 г. в Москве, по официальным данным, число трудовых мигрантов сократилось на $40 \%$. Это обстоятельство вызвало дефицит на московском рынке труда в традиционно «мигрантских» сферах: ЖКХ, строительство, сфера услуг. По данным сервисов по поиску работы, на фоне пандемии количество вакансий курьеров и таксистов в столице увеличилось более чем на 80\% (РБК 2020), По данным Мосстата, в 2021 г. наблюдается пусть и небольшой, но прирост иностранных трудовых мигрантов. С января по октябрь 2021 г. он составил почти пять с половиной тысяч человек (Мосстат 2021). Однако это, конечно же не восполнило дефицит рабочего персонала в логистике, доставке, транспорте, строительстве. Из-за оттока мигрантов все также не хватает водителей, курьеров, диспетчеров, складских работников (Vuz 24.ru 2021).

Чтобы восполнить нехватку работников в сфере ЖКХ, Москва привлекает больше техники: в частности, специализированные машины для ремонта и уборки дорог и обочин, сбора и вывоза мусора, обслуживания инженерных коммуникаций. 
В строительстве также ручной труд постепенно вытесняется автоматизацией (РБК 2020). В конце ноября этого года мэр столицы С. Собянин, заявил о программе постепенного вытеснения и замещения мигрантов на ключевых городских строительных проектах. По словам мэра, сфера строительства - это традиционная для москвичей и российских специалистов, приезжающих в Москву из других регионов страны, сфера труда. Кроме того, они имеют более высокий уровень квалификации. К концу осени 2021 г., по заявлению С. Собянина, число мигрантов, работающих на стройках Москвы, уменьшилось более чем в два раза (ТАСС 2021б). Следовательно, можно констатировать изменение политики московских властей в строительной трудовой сфере не в пользу мигрантов.

Теперь перейдем к результатам опроса москвичей летом этого года. Подавляющее большинство опрошенных (83\%) видят необходимость применения труда мигрантов в своем регионе, при этом существенно меньше тех, кто считает, что труд мигрантов помогает экономике страны (54\%)). Лишь пятнадцатая часть полагает, что труд мигрантов в Москве не нужен вообще, и треть москвичей не видит вклада иностранных работников в экономику города.

В первую очередь (с этим согласны две трети респондентов) труд иностранных трудовых мигрантов следует использовать в сфере ЖКХ (уборка домов и территорий, другие жилищно-коммунальныеуслуги), а также в дорожных работах и строительстве. Отметим, что несмотря на то, что в предыдущие годы у части местных жителей наблюдалось недовольство качеством работ мигрантов в строительной сфере, и несмотря на переориентацию политики городской власти в этой сфере на местные и российские трудовые ресурсы, сами жители города все еще хотят видеть мигрантов на стройках. А вот принимать мигрантов в качестве водителей общественного транспорта и такси, несмотря на уже сложившуюся ситуацию, москвичи не очень готовы. Возможно, это объясняется опасениями москвичей по поводу своей безопасности, умения мигрантов быстро ориентироваться в незнакомом иноязычном городе и плохого знания русского языка, что может затруднить общение во время поездки. Кроме того, транспортная сфера, а также торговля, сельское хозяйство, заводы и фабрики, общепит, охранная сфера (магазины и парковки), оказание услуг частным лицам (работа на приусадебных участках, нянями в семьях и пр.) - это сферы труда, в которых готовы видеть мигрантов менее 50\% респондентов. По всей видимости, можно говорить о некоторой конкуренции в этих трудовых нишах.

Сферы, куда местное население столицы почти не готово пускать мигрантов, это медицина и социальные услуги. На это согласна лишь десятая часть опрошенных. Скорее всего, это обусловлено тем, что здесь требуются специалисты высокой квалификации, а также нежеланием местных жителей пускать «чужаков» в жизненно важные сферы.

Что касается мнения москвичей о конкуренции на рынке труда, то динамика распределений ответов на вопрос «Как Вам кажется, приезжие из других государств отнимают работу у местных жителей?» показывает, что в предпандемийном 2019 г. жители столицы наиболее остро чувствовали конкуренцию со стороны мигрантов, однако в текущем году значительно увеличилось число респондентов, считающих, что местные жители сами не хотят занимать некоторые рабочие места, и существенно сократилось число опрошенных, разделяющих мнение, что мигранты отнимают работу у местных жителей. При этом на протяжении последних лет практически 
неизменной остается доля респондентов (около трети), полагающих, что мигранты в Москве занимают, как и не пользующиеся спросом у местного населения трудовые ниши, так и вытесняют москвичей в некоторых сферах труда (рис. 3).

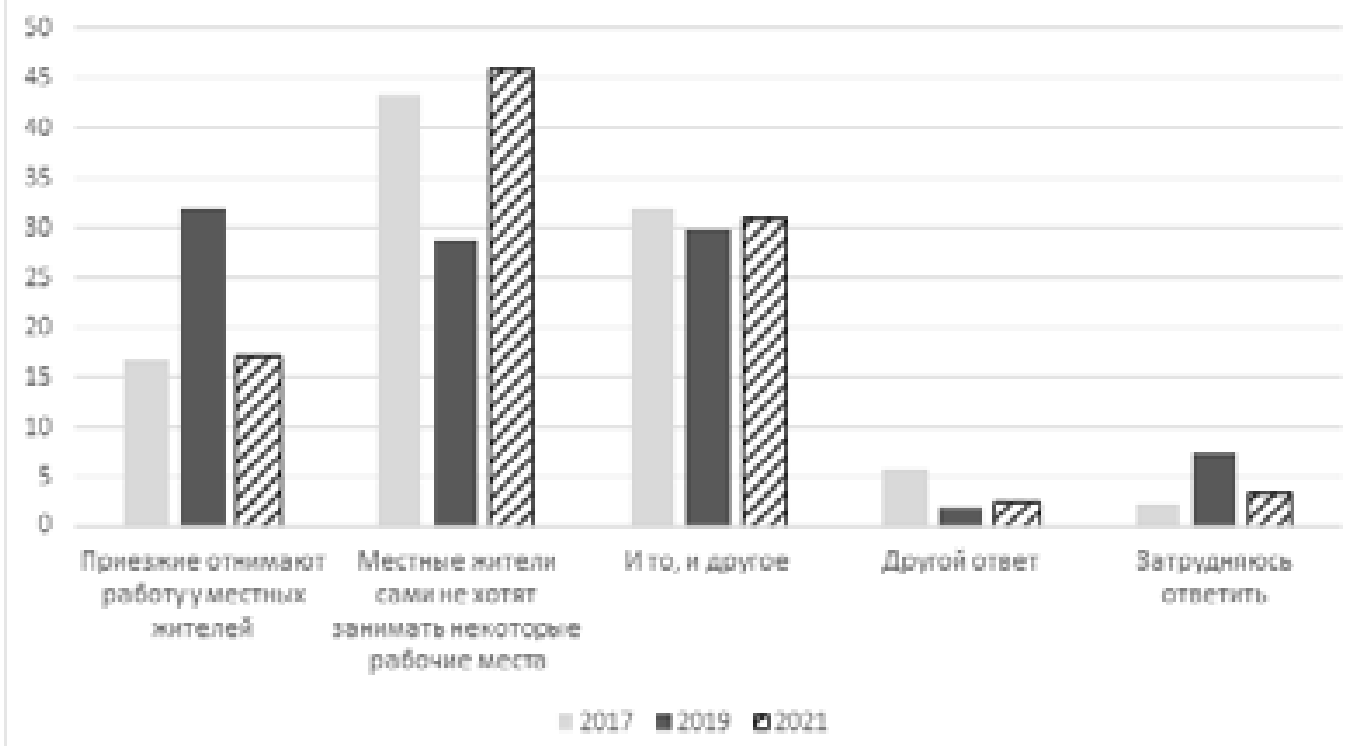

Рис. 3. Мнение москвичей о конкуренщии на рынке труда, в \%.

Fig. 3. Moscow residents' opinion on competition on the labor market, \%.

Резюмируя, можно сказать, что в столичном регионе, с одной стороны, сложилось устойчивое распределение трудовых ниш между москвичами и мигрантами, и такое распределение вполне устраивает основную массу жителей города. С другой стороны, наличие целого ряда профессий, в которые москвичи предпочли бы не пускать мигрантов, а также тот факт, что почти половина жителей города разделяет мнение о том, что мигранты в той или иной степени отнимают работу у местных, может свидетельствовать о наличии некоторой социальной напряженности и конкуренции в определенных трудовых сферах. Однако в целом жесткой конкуренции на столичном рынке труда не наблюдается. К этому добавим, что часть населения столицы не желает видеть мигрантов в тех или иных сферах не потому, что стремится сама занять эти трудовые места, а из соображений безопасности для здоровья или в силу сомнений в компетентности мигрантов. При этом напомним, что подавляющее большинство опрошенных видят необходимость привлечения иностранных трудовых мигрантов в столичном регионе.

\section{Контакты местного населения с мигрантами}

По результатам опроса 2021 г. с мигрантами с разной степенью периодичности общается немногим более половины местных жителей. Не общаются или практически не общаются с ними $41 \%$ респондентов. Здесь необходимо отметить, что для большинства москвичей мигранты ассоциируются с представителями Средней Азии.

Среди респондентов, взаимодействующих с мигрантами, больше тех, кто делает это очень редко. На втором месте стоит ответ «Общаюсь практически ежедневно», 
однако в большинстве случаев он подразумевает лишь общение с курьерами, продавцами, кассирами, дворниками и пр. Небольшая, пятая, часть населения столицы имеет контакты с мигрантами по работе. Очень незначительное число опрошенных заявили о дружеских контактах (5,5\%). Еще меньшее число людей общается с мигрантами в ходе проведения последними строительных и ремонтных работ (2,5\%). Характер общения с мигрантами большей части москвичей очень хорошо иллюстрирует комментарий одного из респондентов (м, 28 лет): «Смотря что понимать под общением. Контактирую с представителями стран ближнего зарубежья, трудоустроенных на низкоквалифицированные рабочие места, каждый день. Деловые контакты по работе с иностранными трудовыми мигрантами - несколько раз в год. Бытового, неформального общения с иностранными трудовыми мигрантами нет».

Главным препятствием для более глубокого общения, согласно результатам опроса, является недостаточное знание мигрантами русского языка. Об этом заявили две трети опрошенных. Другое, значимое, препятствие - это несвойственное для москвичей поведение мигрантов (треть опрошенных). Интересно, что под несвойственным для себя поведением часть местных жителей подразумевает такие общечеловеческие качества, как наглость, неуважение, хамство, агрессивное, вульгарное поведение, нечистоплотность, громкая речь, озлобленность, вспыльчивость, высокомерие.

Отмечается также несоответствие общепринятым в Москве социальным нормам: невоспитанность, несоблюдение правил этикета, отсутствие культуры, нарушение личного пространства, слишком вольное обращение с местными женщинами. Отталкивают от себя мигранты еще и тем, что, по мнению ряда опрошенных, стремятся обмануть, недоделать работу, сделать ее некачественно, взяться за то, что делать не умеют.

Для десятой часть опрошенных препятствием для общения с мигрантами являются культурные различия. Местных жителей отпугивает стайное поведение мигрантов, речь на незнакомом языке (некоторых москвичей этот даже возмущает), ношение национальной одежды, прослушивание национальной музыки, другое вероисповедание и многодетность мигрантов. Один из респондентов указал на скрытый страх перед мигрантами: «Сидят на корточках посреди улиц, ходят в национальных костюмах, которые у славян вызывают плохие ассоциации с терроризмом».

В ходе опроса мы предлагали респондентам описать образ мигранта, каким они его видят. Москвичи поделились на две группы, для которых существует разный образ мигранта. К первой (отметим, что менее многочисленной) группе относятся те, кто считает, что мигрант - это наемный работник, низкоквалифицированный и низкообразованный, ленивый, не знающий русский язык, местные традиции и обычаи и не уважающий их, не ориентирован на адаптацию и интеграцию в местное сообщество. Респонденты из этой категории также озвучивали идеальный в их представлении образ мигранта - лицо, которое с целью найма на работу на законных основаниях приезжает в другую страну с целью заработка; человек, знающий русский язык, культурный, воспитанный, беззлобный, законопослушный, чтит местные традиции.

В образе мигранта у другой группы респондентов (почти у двух третей) присутствуют положительные и сочувственные оттенки: это рабочая сила, которая получает низкую зарплату, не имея прав; это работящий человек, замученный, но смелый, рискнувший приехать в другую страну на заработки ради блага своей семьи, поскольку не имеет возможностей заработать у себя на родине. Мигрант 
обладает такими качествами как доброжелательность, скромность, решительность, ответственность, аскетизм, трудолюбие, работоспособность, умение планировать свою работу и др.

\section{Интеграционные установки москвичей в отношении мигрантов}

В ходе летнего опроса 2021 г. мы спрашивали у респондентов, считают ли они, что нужно стремиться интегрировать мигрантов в принимающее сообщество. Две трети москвичей согласны с этим утверждением. Но довольно значительная (пятая) часть полагает, что этого делать не надо. Десятая часть москвичей, кроме того, полагает, что нет даже необходимости информировать мигрантов о местных традициях и культуре путем распространения информационных листовок или привлечения мигрантов к общественной жизни. Если рассмотреть динамику мнения москвичей об основных мерах адаптации и интеграции за последние несколько лет, то становится ясно, что по сравнению с 2017 г. все больше столичных жителей выступает за усиление этих мер. Увеличилось число москвичей, считающих, что только информационной поддержки путем распространения листовок недостаточно (рис. 4).

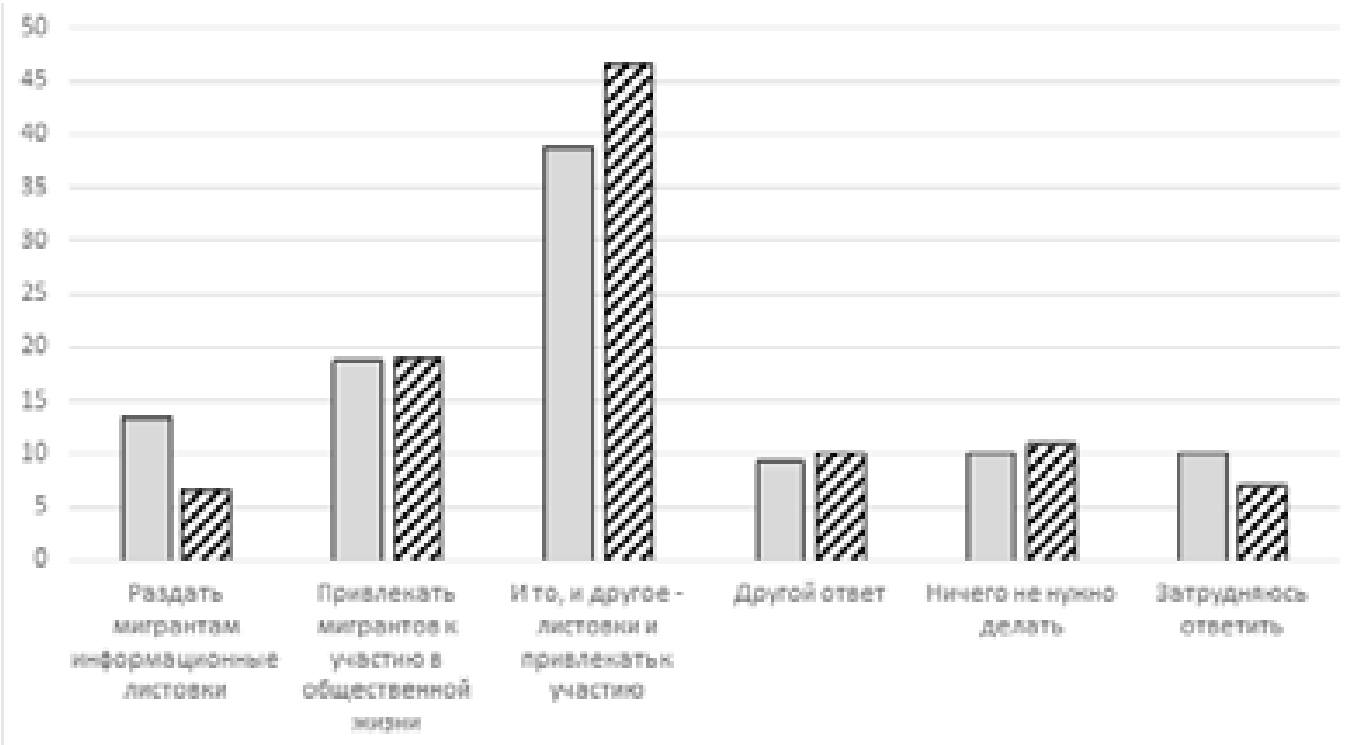

0201702021

Рис. 4. Как информировать мигрантов о местных традициях и культуре? (в \%). Fig. 4. How should we raise migrants' knowledge of local traditions and culture? (\%).

Десятая часть опрошенных выступает в определенном смысле за усложнение интеграционных мероприятий и ограничение числа мигрантов, которым интеграция требуется. Во-первых, мигрантов не надо пускать на территорию Российской Федерации без экзаменов по истории России, русскому языку, правилам поведения и русским традициям. Без сдачи такого экзамена визы не выдавать. Еще один вариант - это принудительное обучение мигрантов вышеперечисленному в специальных школах, некоторые предлагают закрепить это требование законодательно. Кроме 
того, надо не только информировать, но и требовать от мигрантов соблюдения российских традиций и культуры. В общественных местах обязать их разговаривать на языке страны, в которой находятся. При несоблюдении мигрантами предлагаемых мер, высылать их из страны.

Лишь $40 \%$ опрошенных считает, что государство должно поддерживать всех мигрантов и помогать им. Часть москвичей делала уточнения, что государственная поддержка необходима только в отношении легальных, желательно высококвалифицированных, мигрантов. Для основной массы поддержка должна заключаться только в информировании о правилах поведения и обучении местным традициям и культуре. Указывалось также на необходимость помощи в первую очередь гражданам России, а после решения всех проблем местных жителей, можно начать оказывать поддержку мигрантам.

Не очень охотно москвичи поддерживают идею о предоставлении всем без исключения трудовым мигрантам юридической, медицинской помощи, помощи в трудоустройстве и повышения профессиональной квалификации в специальных центрах. За это выступает менее трети опрошенных. Пятнадцатая часть согласна с такой идеей, но помощь, по их мнению, в таких центрах следует оказывать только тем, кто намерен остаться жить в России. Бо́льшая часть москвичей (40\%) полагает, что если и оказывать государственную помощь, то только при условии, что мигранты будут за это платить. В случае создания таких специализированных центров почти половина местных жителей не стала бы их посещать для решения собственных проблем и почти четверть опрошенных затруднилась с ответом.

В последние годы наблюдается уменьшение числа москвичей, которые отнесутся положительно к совместному обучению своих детей и внуков с мигрантами, и увеличивается доля тех, кто отнесется к этому нейтрально (рис. 5).

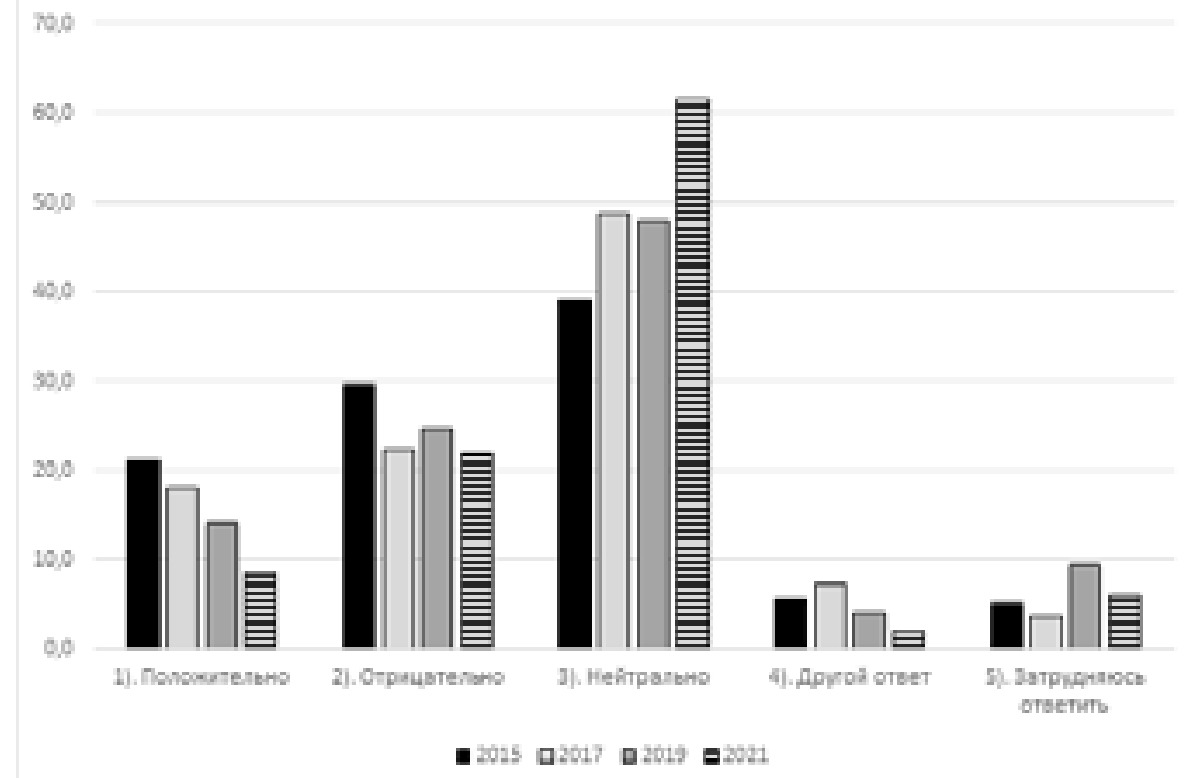

Рис. 5. Как Вы относитесь к совместному обучению своих детей с мигрантами? (в \%)

Fig. 5. How do you feel about your children and migrants' joint education? (\%). 
Для признания москвичами иностранца своим соотечественником все большее значение приобретают принадлежность его к бывшим гражданам СССР, а также знание русского языка (рис. 6).

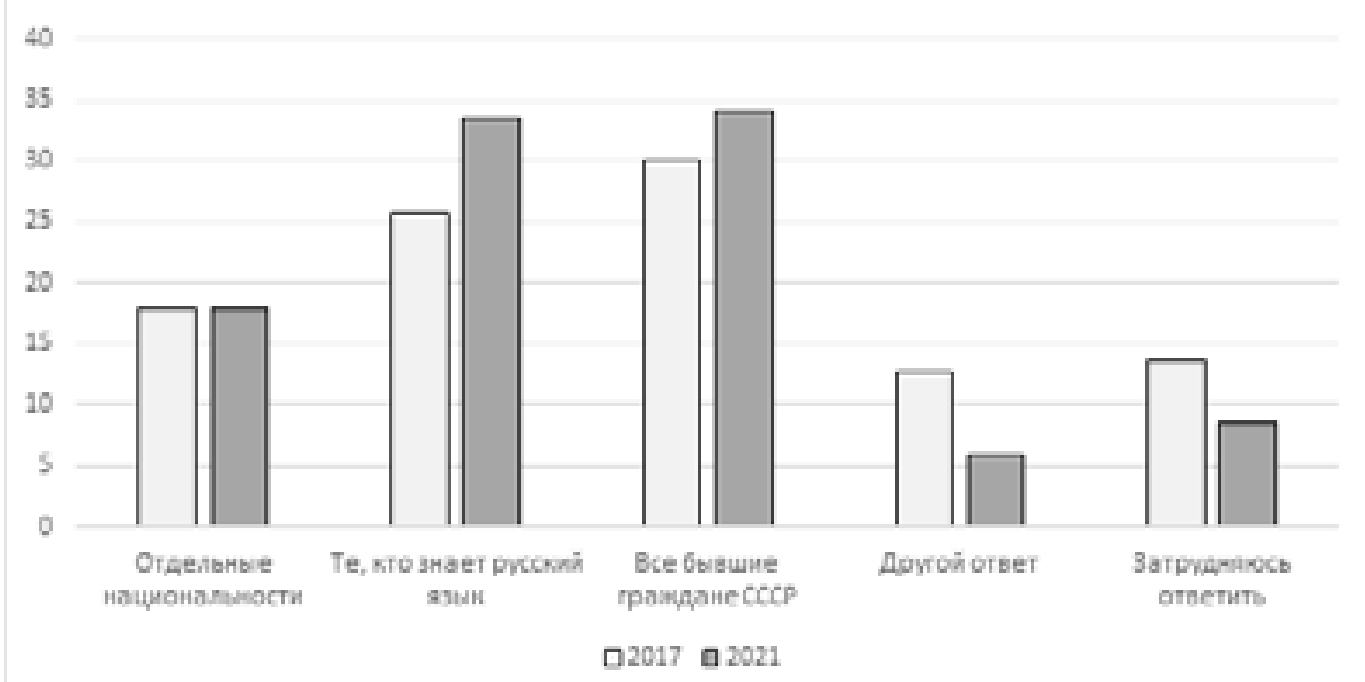

Рис. 6. . Какие иностранцьь должны быть названы соотечественниками, в \%. Fig. 6. Which foreigners should be regarded as compatriots? (\%).

В целом можно сказать, что жители столицы к настоящему моменту становятся меньше настроенными на интеграцию всех мигрантов в столичное сообщество, при этом отношение к ним характеризуется высокой степенью нейтральности большинства жителей столицы.

\section{Конфликтный потенциал в сфере миграционных отношений}

В отношении конфликтного потенциала в сфере миграционных отношений в Москве можно сказать следующее. Последние несколько лет характеризуются тем, что все больше столичных жителей перестают разделять мнение о большей, по сравнению с местными, преступности среди мигрантов, и возрастает доля москвичей, кто не будет поддерживать акции антимиграционной направленности в случае их возникновения (рис. 7). Как уже было сказано выше, большинство москвичей относятся к мигрантам нейтрально, в представлениях двух третей столичных жителей образ мигранта наделен рядом положительных черт. Но тем не менее конфликтный потенциал в сфере миграционных отношений все же существует: по данным нашего опроса в 2021 г. 15\% населения Москвы заявляют о своей готовности принять активное участие в протестах. В ходе исследования респондентам предлагалось указать страны, жителей которых москвичи не хотели бы видеть на заработках в России. Лидирующее место в таком «миграционном антирейтинге» заняли Таджикистан, Азербайджан и Грузия, также противники иностранной трудовой силы в значительной степени против приезда граждан Киргизии, Узбекистана и Украины.

В предыдущие годы потенциал активного неприятия мигрантов держался приблизительно на том же уровне, что и сейчас, но с учетом сокращения к 2021 г. числа 
не определившихся, а значит, допускающих возможность участия в антимигрантских акциях при определенном стечении обстоятельств, можно говорить о тенденции к незначительному ослаблению уровня активной конфликтности в миграционных отношениях.

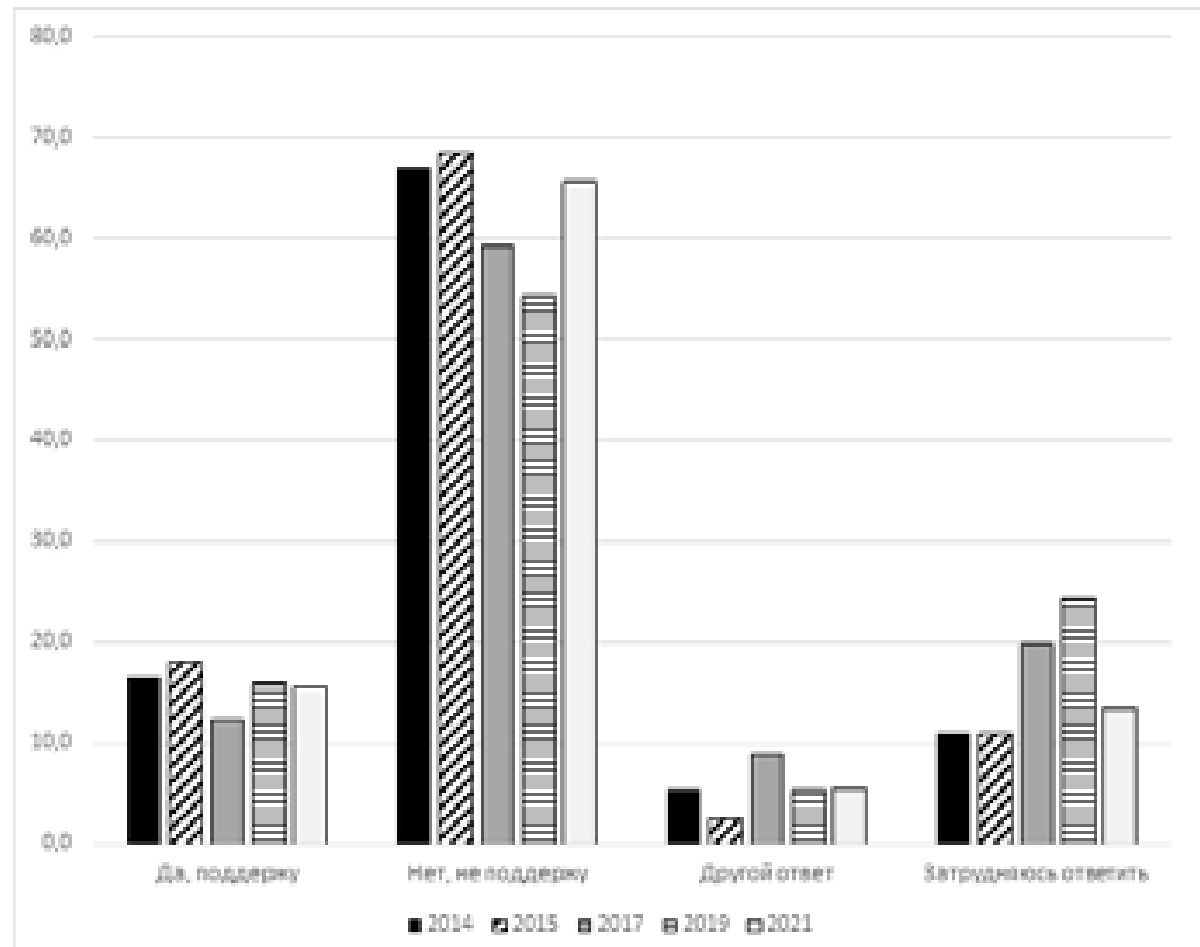

Рис. 7 Если в Вашем городе возникнут пикеты или акиии против иностранных трудовых мигрантов, поддержите или не поддержите такие пикеты и акции? (в \%).

Fig. 7. Would you support protests against foreign labor migrants if they broke out in your town? (\%).

\section{Основные выводы}

- Две трети населения Москвы находятся в достаточно благополучной социально-экономической ситуации. Треть жителей города испытывает трудности. В последние годы в Москве наблюдается тенденция увеличения уровня тревожности населения по поводу потери работы и источников доходов. Согласно результатам исследования, несмотря на позитивную официальную риторику, многие москвичи говорят о существовании в российской столице целого ряда проблем социально-экономического характера. Подавляющее болышинство опрошенных видит необходимость осуществления мер для улучшения качества жизни в городе.

- Н Насковском рынке труда отсутствует жесткая конкуренция между местным населением и мигрантами. Мигранты в основном занимают низкооплачиваемые ниши малоквалифицированного труда, а местные жители не против этого, поскольку такая работа их не привлекает. Однако есть ряд трудовых сфер, в которых возможно напряжение: транспорт, торговля, сельское хозяйство, заводы и фабрики, общепит, охранная сфера (магазины и парковки), работа 
по найму у граждан (на приусадебных участках, няни в семьях и др.).

- Подавляющее большинство столичных жителей видит необходимость привлечения иностранных трудовых мигрантов в столичном регионе, но только половина респондентов уверена в том, что труд мигрантов помогает экономике города и страны.

- Москвичи в недостаточной степени настроены на интеграцию всех работающих в столице мигрантов. В первую очередь они готовы интегрировать тех, кто хорошо знает русский язык и готов остаться в стране. Миграционные отношения в столице можно охарактеризовать как в большей степени нейтральные, но конфликтный потенциал (активное неприятие мигрантов со стороны части местного населения) существует и составляет $15 \%$.

- $\quad$ В подавляющем большинстве москвичи не связывают свои проблемы социально-экономического характера с присутствием в регионе мигрантов. Одним из виновников неблагополучной социально-экономической ситуации называются органы региональной власти различного уровня.

\section{Источники и материалы}

Мосстат 2021 - Миграция населения. Общие итоги миграции населения за январь-октябрь 2021 года // https://mosstat.gks.ru/folder/64634 (дата обращения 28.11.2021).

Официальный сайт Мэра Москвы 2021 - Социальная поддержка // https://www.mos.ru/otvetsocialnaya-podderjka/ (дата обращения 10.12.2021).

РБК 2020 - Гастарбайтеры подвели перевозку и доставку // https://www.rbc.ru/newspaper/202 0/11/03/5f9bf5269a794771485ceb51 (дата обращения 28.11.2021).

РИА рейтинг: Россия сегодня 2021 - Обзор: социально-экономическое положение регионов РФ в І пол. 2021 г. // https://riarating.ru/regions/20210921/630208818.html (дата обращения 28.11.2021)

Социально-экономическое положение регионов РФ 2021 - Аналитический бюллетень «Социально-экономическое положение регионов РФ». Выпуск 43. Итоги января - июня 2021 года// http://vid1.rian.ru/ig/ratings/regions_demo43.pdf. С. 6.

ТАCC 2021a - Уровень безработицы в Москве в 2020 году стал одним из самых низких среди мегаполисов мира // https://tass.ru/obschestvo/11104935 (дата обращения 10.12.2021).

ТАСС 20216 - Собянин заявил, что в Москве количество мигрантов на стройках снизилось более чем вдвое // https://news.mail.ru/economics/48872587/ (дата обращения 28.11.2021).

ТВЦ 2021 - Собянин оценил социально-экономическое развитие Москвы // https://www.tvc. $\mathrm{ru} /$ news/show/id/223256 (дата обращения 28.11.2021).

RT на русском 2021 - Инвестиции в экономику Москвы превысили 2,5 трлн рублей в 2021 году // https://russian.rt.com/business/news/938329-moskva-investicii-ekonomika (дата обращения 13.12.2021).

Vuz 24.ru 2021 - Рынок труда и самые востребованные профессии в 2021 году в России // https://vuz24.ru/news/karera-i-trudoustroystvo/rynok-truda-i-samye-vostrebovannye-professiiv-2021-godu-v-rossii (дата обращения 10.12.2021).

\section{Научная литература}

Вакуленко Е.С. Ведет ли миграция населения к межрегиональной конвергенции в России? // Вестник НГУЭУ. 2013. № 4. С. 239-264.

Коровкин А.Г., Долгова И.Н., Единак Е.А. Анализ взаимосвязи внутренней миграции и социально-экономической дифференциации регионов (на примере Центрального федерального округа) // Научные труды: Институт народнохозяйственного прогнозирования РАН. М.: МАКС Пресc, 2013. Т. 11. С. 71-94. 
Кариева М.А., Мкртчян Н.В., Флоринская Ю.Ф. Миграция в России и социально-экономическое развитие регионов: анализ взаимного влияния // Проблемы прогнозирования. 2020. № 4. C. 87-97.

Кульбачевская О.В. Межэтнические отношения на рынке труда в Москве: опрос экспертов // Московская модель этнической политики. Ред. Кульбачевская О.В., Степанов В.В. Москва: ИЭА РАН, 2015. С. 366-377.

Мартынова М.Ю. Миграции в России: опыт культурной интеграции через повседневные услуги // Вестник российской нации, 2018, № 2. С. 114-127.

Миграция и мигранты в России и мире: опыт социально-антропологических и этнографических наблюдений (ред. Степанов В.В.) Москва: ИЭА РАН, 2015-2016. 285 с.

Степанов B.B. Межэтнические отношения на рынке труда в Москве: массовый опрос населения // Московская модель этнической политики. Ред. Кульбачевская О.В., Степанов В.В. Москва: ИЭА РАН, 2015. С. 343-366.

Степанов B.B. Общественное восприятие миграции и мигрантов в современной России // Миграция и мигранты в России и мире: опыт социально-антропологических и этнографических наблюдений. Ред. Степанов В.В. Москва: ИЭА РАН, 2016. С. 109-115.

Тишков В.А., Степанов В.В., Барышная Н.А., Кульбачевская О.В., Мартыненко А.В., Мартынова Е.П., Мокин К.С., Подлесных О.Н., Савин И.С., Черных А.В. Миграция и межнациональные отношения: ресурс государственно-общественного партнерства в России. Москва: ИЭА РАН, 2019. 340 с.

Etzo Ivan. Internal Migration and Growth in Italy. MPRA Paper, University Library of Munich, Germany. 2008.

Greenwood M. A Regression Analysis of Migration to Urban Areas of a Less-developed Country: The Case of India // Journal of Regional Science. 1971. № 11(2). Pp. 253-262.

Hugo G. Care Worker Migration, Australia and development // Population, Space and Place. Vol. 15. Issue 2, March 2009. Pp. 189-203.

Liu Y., Shen J. Spatial Patterns and Determinants of Skilled Internal Migration in China, 20002005. (Article) Papers in Regional Science. Vol. 93. Issue 4, 1 November 2014. Pp 749-771.

Yap L. Internal Migration and Economic Development in Brazil // Quarterly Journal of Economics. 1976. № 90 (1). Pp. 119-137.

\section{References}

Etzo, Ivan. 2008. Internal Migration and Growth in Italy. MPRA Paper, University Library of Munich, Germany.

Greenwood, M. 1971. A Regression Analysis of Migration to Urban Areas of a Less-developed Country: The Case of India. Journal of Regional Science 11 (2): 253-262.

Hugo, G. 2009. Care Worker Migration, Australia and development. Population, Space and Place 15 (2, March): 189-203.

Karceva, M.A., Mkrtchyan, N.V., Florinskaya, Yu.F. 2020. Migraciya v Rossii i social'no-ekonomicheskoe razvitie regionov: analiz vzaimnogo vliyaniya [Migration in Russia and socio-economic development of regions: analysis of mutual influence]. Problemy prognozirovaniya 4: 87-97.

Korovkin, A.G., Dolgova, I.N., Edinak, E.A. 2013. Analiz vzaimosvyazi vnutrennej migracii i social'no-ekonomicheskoj differenciacii regionov (na primere Central'nogo federal'nogo okruga) [Analysis of the relationship between internal migration and socio-economic differentiation of regions (on the example of the Central Federal District)]. Nauchnye trudy: Institut narodnohozyajstvennogo prognozirovaniya RAN. Moscow: MAKS Press 11: 71-94.

Kulbachevskaya, O.V.2015. Mezhetnicheskie otnosheniya na rynke truda v Moskve: opros ekspertov [Interethnic relations on the labor market in Moscow: a survey of experts] In Moskovskaya model' etnicheskoj politiki [Moscow Model of ethnic policy], edited by O.V. Kulbachevskaya, V.V. Stepanov. Moscow: IEA RAS. 
Liu, Y., Shen, J. 2014. Spatial Patterns and Determinants of Skilled Internal Migration in China, 2000-2005. (Article) Papers in Regional Science 93 (4, 1 November): 749-771.

Martynova, M.Y. 2018. Migratsii v Rossii: opyt kul'turnoi integratsii cherez povsednevnye uslugi [Migration in Russia: Experience of Cultural Integration through Daily Services]. Vestnik rossiiskoi natsii 2: 114-127.

Stepanov, V.V. 2015. Mezhetnicheskie otnosheniya na rynke truda v Moskve: massovyj opros naseleniya [Interethnic relations in the labor market in Moscow: a mass survey of the population] In Moskovskaya model' etnicheskoj politiki [Moscow Model of ethnic policy], edited by O.V. Kulbachevskaya, V.V. Stepanov. Moscow: IEA RAS.

Stepanov, V.V. 2016. Obshchestvennoe vospriyatie migracii i migrantov v sovremennoj Rossii [Public perception of migration and migrants in modern Russia] In Migraciya i migranty $v$ Rossii $i$ mire: opyt social'no-antropologicheskih i etnograficheskih nablyudenij [Migration and migrants in Russia and the world: experience of socio-anthropological and ethnographic observations.], edited by V.V. Stepanov. Moscow: IEA RAS.

Stepanov, V.V.(ed). 2015-2016. Migraciya imigrantyv Rossii imire: opyt social'no-antropologicheskih i etnograficheskih nablyudenij [Migration and migrants in Russia and the world: the experience of socio-anthropological and ethnographic observations]. Moscow: IEA RAS.

Tishkov, V.A., Stepanov, V.V., Baryshnaya, N.A., Kulbachevskaya, O.V., Martynenko, A.V., Martynova, E.P., Mokin, K.S., Podlesnyh, O.N., Savin, I.S., Chernyh, A.V. 2019. Migraciya $i$ mezhnacional'nye otnosheniya: resurs gosudarstvenno-obshchestvennogo partnerstva $v$ Rossii [Migration and Interethnic Relations: a Resource of Public-public partnership in Russia]. Moscow: IEA RAS.

Vakulenko, E.S. 2013. Vedet li migraciya naseleniya k mezhregional'noj konvergencii v Rossii? [Does population migration lead to interregional convergence in Russia?]. Vestnik NGUEU (Novosibirsk State University of Economics and Management) 4: 239-264.

Yap, L. 1976. Internal Migration and Economic Development in Brazil. Quarterly Journal of Economics 90(1): 119-137. 